\title{
HAEMATOLOGICAL AND BLOOD BIOCHEMICAL PARAMETERS OF PRE - AND POST LAMBING PERIODS FOR IRAQI NUAEMIE EWES
}
A.H. Awad ${ }^{1}$
M. A. Ismaeel ${ }^{1}$
Z. T. AL-doori ${ }^{2}$
Assist. Prof.
Assist. Prof.
Assist. Prof.

${ }^{1}$ Dept. Medicine, Surgery and Obstetrics, Coll.Veterinary Medicine University of Tikrit

${ }^{2}$ Dept. Public Health, Coll. Veterinary Medicine, University of Tikrit

Email: ziyadaldoori@gmail.com

\section{ABSTRACT}

The present study designed to investigate the hematological and blood biochemical changes in pre and post lambing periods in Iraqi Nuaemie ewes. Ten Nuaemie ewes weighed 35-45 kg and aged between 23 years were reared in animal's house of Veterinary College / Tikrit University from October-2018 to March-2019, Ten $\mathrm{ml}$ of blood samples were collected from each animal during the periods of last gestation month, at lambing and 2 weeks thereafter, Two and half $\mathrm{ml}$ of blood samples were collected in EDTA- containing tubes to determine the hematological parameters and the remaining was used to separate serum and stored at $-\mathbf{2 0}^{\circ} \mathrm{c}$ for blood biochemical assessment. The results revealed decreased in total red blood cells, haemoglobin and packed cell volume during post lambing period. The total white blood cells count and neutrophils were decreased during the post-partum period, while the lymphocyte was decreased at the day of lambing $(\mathbf{5 0} \pm 5.8 \%)$. The biochemical parameters exhibited lesser total protein concentrations at the day of lambing $(6.5 \pm 1.85 \mathrm{~g} / \mathrm{dl})$ while greater glucose, cholesterol and triglyceride concentrations during post-partum period. The concentration of urea and creatinine increased during the pre-partum period whereas, LDL and HDL concentrations increased in post- lambing period. The minerals concentrations revealed lesser concentrations of Zink and iron during the post-partum period while, copper concentration was greater during similar period. In conclusion, the physiological status of animals have clearly effects on the haematological and biochemical parameters in Iraqi Nuaemie ewes.

Key words: hematology, blood biochemistry, lambing, nuaemie ewes, Iraq.

عواد وآخرون مجلة العلوم الزراعية العراقية -948-941:52: 521 (4) ماتية

المعايير الامية والكيموحيوية للام لمدة قبل ويعد الولادة في النعاج النعيمية العراقية

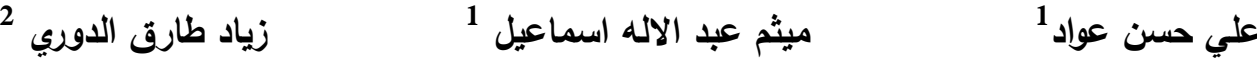

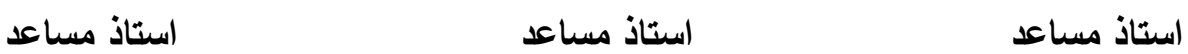

$$
\begin{aligned}
& 1 \text { فرع الطب الباطني والجراحة والتوليد, كلية الطب البيطري, جامعة تكريت } \\
& 2 \text { فرع الصحة العامة, كلية الطب البيطري, جامعة تكريث }
\end{aligned}
$$

صممت الدراسة الحالية لبيان التغيرات الدمية والكيمو حيوية للام قبل ويعد الولادة لاى النعاج النعيمية العراقية. استخدت في هذه الدراسة عشرة نعاج نعيمية تراوحت اوزانها بين 35-45 كفم واعمارها بين 2-3 سنة ربيت في البيث الحيواني التابع لكلية الطب البيطري جامعة تكريث للمدة من تثرين الاول 2018 ولغاية اذار 2019 تم جمع 10 مل من الام في الثهر الاخير من الحمل وعند الولادة ويعد اسبوعين من الولادة, 2.5 مل وضعت فئ في انابيب حاوية على مانع التخثر لحساب المعايير الدمية والباقي استخلم لعزل المصل وحفظه بلرجة 20 تحت الصفر لغرض قياس المعايير الكيموحيوية

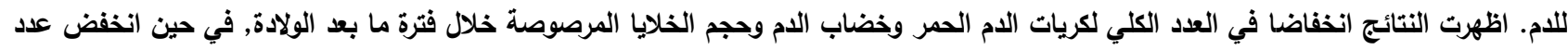
خلايا الام البيضاء الكلية والخلايا الحمضية وعدد الخلايا اللمفية عند يوم الولادة. اظهرت نتائج التحليلات الكيموحيوية انخفاضا في تركيز البروتين الكلي عند الولادة بينما انخفض تركيز كل من الكلوكوز , الكولسترول واللدهون الثثلاثية في الفترة ما بعد الولادة, في الوقت الذي ارتفع فيه مستوى كل من اليوريا والكرياتنين خلال فترة ما قبل الولادة. اما تركيز كل من البروتينات الدهنية المنخفضة والمرتفعة الكثافة فقد ازدادت لمدة مادئ ما بعد الولادة.

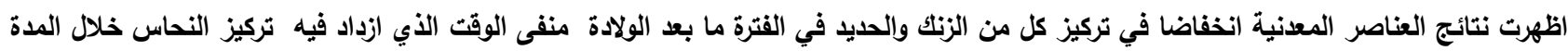

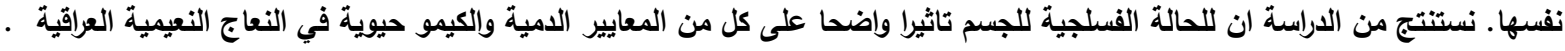
الكلمات المفتاحية: المعايير الدمية , المعايير الكيموحيوية, الولادة, النعاج النعيمية, العراق. 


\section{INTRODUCTION}

Pregnancy, parturition, and lactation represent a physiological state of the body, which activates adaptation mechanisms purposed at maintaining normal homeostasis during the pre-partum period (23). The haemoglobin and packed cell volume values, were sequentially observed in goats and sheep during pre-partum period, generally reflect an increase in these values in late gestation followed by a decrease in the pre-lambing period and a further decrease in early lactation $(12,22)$. Additionally, total white blood cells may be increase in late pregnancy in sheep (47), because of an ACTH-related hormonal stress reaction. Stress and neuroendocrine changes have a direct influence on the neutrophils, and lymphocytes counts during a per-partum period (31) Biochemical parameters vary during different physiological stages of animals (5). Pregnancy and lactation are two most important stages in the life of animals, which affect metabolism resulting in the alteration of the haemato-biochemical profile (33). Hence, biochemical parameters including total protein, triglycerides, free fatty acids, and urea are important indicators of the metabolic activity in lactating animals (29).In ruminants, number of factors like season, and physiological variations such as those in pregnancy, and lactation can effect on serum chemistry and minerals levels (49). The present study was designed to determine an alteration in the concentrations of haematological and some biochemical parameters during pre and postpartum periods in Iraqi Nuaemie ewes.

\section{MATERIALS AND METHODS}

Animals: Ten healthy adult ewes, aged between 2-3 years with an average body weight of $35 \pm 45 \mathrm{~kg}$ were used. All animals were apparently healthy on clinical examination, treated against internal parasite by (Ivomec $\AA)$. The animals reared in semi closed pens in animal's house of Veterinary medicine College / Tikrit University.

Hematological examinations: Ten $\mathrm{ml}$ of blood samples were collected via jugular venipuncture from all ewes by disposable syringes, $2.5 \mathrm{ml}$ were taken in tube containing EDTA to determine the total red blood cells
(RBC) and white blood cells (WBC) by haemocytometer, while differential leukocyte counts were estimated by Giemesa-stained blood films. Haemoglobin $(\mathrm{Hb})$ was determined by the Sahli method, while packed cells volume (PCV) was determined using microhaematocrit method as described by (15). The rest of blood samples were centrifuged at $3000 \mathrm{rpm}$ for 10 minute then, serum was harvested and stored at $-20{ }^{\circ} \mathrm{c}$ until assay. Blood biochemical parameters (total serum proteins, albumin, glucose ,urea, creatinine, cholesterol, HDL-cholesterol, LDL cholesterol, and triglycerides), were measured by spectrophotometer with special kit \{Biomeghrib Company (Maghrib) as described by (46, 21 and 24), iron, copper and zinc were estimated by spectrophotometer with special kit \{BiolabSA/France) as described by (46, 16 and 25), at the Clinical Pathology Lab., Collage of Veterinary Medicine, University of Tikrit.

Statistical analysis: Data were analysed using paired t-test (a Repeated Measures ANOVA) in SPSS (Version 19; SPSS). The differences were set at $\mathrm{p}<0.05(6)$.

\section{RESULTS AND DISCUSSION}

The results of present study revealed (Table: 1) significantly $(P \leq 0.05)$ increased in TRBCs at lambing $(6933000 \pm 3.66 \mathrm{cell} / \mu \mathrm{l})$ and decreased in pre and post-partum (5944666 \pm $1.05,4568000 \pm 1.3$ cell $/ \mu 1$ respectively). The result of $\mathrm{Hb}$ was showed significant $(\mathrm{P} \leq 0.05)$ increased during the pre-partum period $(9.2 \pm$ $1.7 \mathrm{~g} / \mathrm{dl}$ ) compared with the day of lambing and post-partum period. The PCV was significantly $(\mathrm{P} \leq 0.05)$ decreased during the post-partum period $(26.4 \pm 10.7 \%)$ compared with the pre-partum and at the day of lambing $(29.3 \pm 6.3$ and $28.9 \pm 3.7 \%$ respectively). This agreed with those reported by Hassan et al., (20), who noticed a decrease PCV, and $\mathrm{Hb}$ values in lactating animals and postulated a negative association between PCV and milk production. Moreover, PCV was found to decrease in first month of lactation in Barki ewes (17), and it has been suggested that the elevated erythrocyte destruction in mammary cells are responsible for low PCV value along with mobilization of water to mammary gland (11). A similar findings were recorded in goats, where a decrease in 
$\mathrm{HB}, \mathrm{RBCs}$ and PCV were observed during lactation (12). Similar results for $\mathrm{Hb}$ content in lactating desert ewes determined (1). The increase in $\mathrm{RBC}$ volume during later pregnancy causing increased volume of water during advanced pregnancy (30). Increased $\mathrm{Hb}$ content in later pregnancy ewes are probably due to increase demand for oxygen and the requirements of higher metabolic rate for pregnancy. Increase in $\mathrm{Hb}$ content during pregnancy confirmed the results of (17). The fall of $\mathrm{Hb}$ in the blood of goats in lactation were found (12). Decrease in the number of $\mathrm{RBC}$ in the blood of ewes in the early lactation was also reported by (10). Decline in the number of RBC in the blood of ewes in the early lactation are similar to those of (12) in goats.

Table 1. Alterations in the red blood cells $(\mathrm{RBC})$, haemoglobin $(\mathrm{Hb})$ and packed cell volume $(\mathrm{PCV})$ values during pre and post-partum periods in Nuaemie ewes (Mean $\pm \mathrm{SE}$ ).

\begin{tabular}{|llll|}
\hline $\begin{array}{c}\text { Periods } \\
\text { Parameters }\end{array}$ & pre-partum & Day of parturition & post-partum \\
\hline TRBC cell/ $\mu \mathrm{l}$ & $\mathbf{5 9 4 4 6 6 6 \pm 1 . 0 5 b}$ & $\mathbf{6 9 3 3 0 0 0} \pm 3.66 \mathrm{a}$ & $\mathbf{4 5 6 8 0 0 0} \pm 1.3 \mathrm{c}$ \\
Hb g/dl & $9.2 \pm 1.7 \mathrm{a}$ & $7.94 \pm 2.11 \mathrm{~b}$ & $7.2 \pm 3.6 \mathrm{~b}$ \\
PCV \% & $29.3 \pm 6.3 \mathrm{a}$ & $\mathbf{2 8 . 9} \pm 3.7 \mathrm{~b}$ & $26.4 \pm 10.7 \mathrm{c}$ \\
\hline
\end{tabular}

Means with different superscripts within each row differ significantly $(\mathbf{P} \leq \mathbf{0 . 0 5})$.

Table (2) showed an increase of WBCs count $(\mathrm{P} \leq 0.05)$ at day of lambing $(10660 \pm 2.56$ cell $/ \mu 1)$, then decreased during the post-partum period $(8730 \pm 1.34$ cell $/ \mu 1)$. This notion was agreed with Iriadam (22) who showed decreasing in the number of WBC in goats in early lactation compared to pregnant goats. The decrease in WBC counts during lactation in goats blood indicated their migration from blood into milk for more efficient phagocytosis and mammary gland defence against pathogens (39). The increase of WBCs near parturition might be attributed to the antepartum elevated in cortisol (32). The differential count of leukocyte was presented in Table (2), the neutrophils percentage was significantly $(\mathrm{P} \leq 0.05)$ increased at the day of lambing $(48 \pm 1.44 \%)$, while decreased during the pre- and post-partum periods $(44 \pm 2.52 \%$, $41 \pm 1.89 \%$ respectively). The results observed an elevation for lymphocyte count in postpartum period $(58 \pm 1.09 \%)$ but decreased at the day of parturition $(50 \pm 5.8 \%)$. This is similar to what observed by (32). The increase in number of neutrophils near parturition is mediated by antepartum rise in cortisol (42). Similarly to these results Meglia et al., (35) recorded a higher WBC count at the day of lambing than pre- and post- calving. The explanation for these results may come from the migration of lymphocytes into different tissues in relation to neutrophils (41). High levels of cortisol detected at parturition have no effect on adhesion molecules of lymphocytes and for that reason they are able to penetrate in to the tissues (8).

Table 2. Alterations in the white blood cells (WBC) count and its differentiation values during pre- and post-partum periods in Nuaemie ewes (Mean $\pm \mathrm{SE}$ ).

\begin{tabular}{|c|c|c|c|}
\hline $\begin{array}{c}\text { Periods } \\
\text { Parameters }\end{array}$ & pre-partum & Day of lambing & post-partum \\
\hline $\mathrm{WBC} 10^{3} \mathrm{cell} / \mu \mathrm{l}$ & $9427 \pm 1.6 b$ & $10660 \pm 2.56 a$ & $8730 \pm 1.34 b$ \\
\hline Neutrophils \% & $44 \pm 2.52 b$ & $48 \pm 1.44 a$ & $41 \pm 1.89 c$ \\
\hline Lymphocyte \% & $55 \pm 2.43 b$ & $50 \pm 5.8 c$ & $58 \pm 1.09 a$ \\
\hline Eosinophil \% & $1 \pm 4.7 \mathrm{a}$ & $1 \pm 2.03 a$ & $1 \pm 0.66 a$ \\
\hline Basophils \% & $\mathbf{0}$ & $\mathbf{0}$ & $\mathbf{0}$ \\
\hline Monocyte \% & $\mathbf{0}$ & $1 \pm 0.36 \mathrm{a}$ & $\mathbf{0}$ \\
\hline
\end{tabular}

Means with different superscripts within each row differ significantly $(\mathrm{P} \leq \mathbf{0 . 0 5})$.

The results of blood biochemical analysis as showed in Table (3) revealed significant decreasing of total protein concentration at the day of parturition and during the post-Partum period compared with the Pre-partum period $(6.5 \pm 1.85, \quad 6.9 \pm 1 . .24, \quad 7.8 \pm 1.08 \mathrm{~g} / \mathrm{dl}$ respectively). This agreed with those observed by Kalasariya et al., (27) who found out decreasing in total protein at parturition in ewes and goat. These changes in plasma proteins might represent an adaptive response to higher need of water mobilization and protein by blood to mammary glands for milk synthesis. Similar to present findings, Vihan et al., (48) who also reported reduced total protein concentration at the day of calving of buffaloes as compared to their values at pre and post-partum period. In contrast, 
Abdulkareem $(2,3)$ did not find any alterations in total protein concentrations at pre-partum, day of calving and post-partum periods of Iraqi buffaloes. Pandey et al., (40) Also reported the lower level of plasma total proteins after calving in cows. The lower of total protein at time of parturition indicated their high maternal requirements to get transfer towards colostrum synthesis (37), AbdulRahaman et al., (4) noticed similar increasing in concentration of total protein in pregnant camel than non-pregnant and they explained these increasing to an increase synthesis of proteins during pregnancy from the liver, and this is as a result of the higher energy requirement for fetal growth. Similar results were also reported by (26) in goat. The differences in albumin lacked significance during pre-patum, day at lambing and postpartum periods. In contrast, Al-Mujalli (7) reported reduction and subsequent elevated in plasma albumin during post-partum period in dairy cows, while similar findings to the current results was observed by Mohri et al., (37) also did not report any significant effect on plasma albumin levels between day of parturition and pre/post-parturient values. The concentration of glucose was increased $(\mathrm{P} \leq 0.05)$ at the day of lambing $(80 \pm 11.47$ $\mathrm{mg} / \mathrm{dl})$, then decreased during the post-partum period $(55.2 \pm 18.27 \mathrm{mg} / \mathrm{dl})$. These results are in agreement with the findings of Vihan and Rai (48) and EL-Sherif and assad (17), who reported that blood glucose of pregnant ewes started to increase from the beginning of pregnancy and continued increasing to reach the peak at parturition. Moreover, the peak of plasma glucose levels was observed on the last day of pregnancy in dairy sheep (14). The current results were disagreed with thosr reported by Abdulkareem $(2,3)$ who did not noticed any changes in glucose concentrations during pre-partum, at calving and post-partum periods in Iraqi buffaloes. Schlumbohm and Harmeyer (43) previously stated that insulin responsiveness was significantly reduced in sheep during late gestation and lambing, which led to decrease glucose turnover and uptake by muscle and fat tissues. In spite of, the high need for glucose under stress such as pregnancy and parturition, the output of adrenocorticotrophic hormone, glucocorticoids and epinephrine is increased for the breakdown of liver glycogen (13). Higher $(\mathrm{P} \leq 0.05)$ concentrations of urea and creatinine were recorded during the pre-partum period $(40 \pm 0.84$ and $2.2 \pm 1.69 \mathrm{mg} / \mathrm{dl}$ respectively) compared with the day of lambing and postpartum period. This significant $(\mathrm{P} \leq 0.05)$ increases in the levels of urea and creatinine during prepartum period compared with the day of lambing and post-partum periods may be due to the increased in cortisol concentrations that increases the catabolism of protein in the body. This result was in agreement with that found by (44), and Taghipour et al., (45) who stated that the decrease in serum blood urea nitrogen around parturition may be associated with the decline of feed intake due to stress and hormonal changes during lambing. Ozpinar et al., (38) explained the reason of creatinine rises during prepartum period to the using of creatinine in muscle tissue of fetus as well as mother. The current results showed decreasing in the cholesterol and triglyceride concentrations in the post-partum period $(100 \pm 0.35$ and $26 \pm 1.07 \mathrm{mg} / \mathrm{dl}$ respectively) compared with the day of lambing and prepartum period. These results were in agreement with Zumbo et al., (51) who found significant decrease in both cholesterol and triglyceride concentrations after birth due to increased lipoprotein lipase activity, and proved that, the adipose tissue metabolism is strictly related to insulin, which stimulates lipogenesis in pregnant ewes. During lactation period the insulin stimulation of lipogenesis may become inefficient which is confirmed by the significant decrease in serum triglycerides and total cholesterol at post-partum period compared to pre-partum (28). The low-density lipoprotein (LDL) and high- density lipoprotein (HDL) were increased in post-partum period $(59 \pm 2.06$ and $29 \pm 1.8 \mathrm{mg} / \mathrm{dl}$ respectively) in comparison with the day of lambing and pre-partum period. These increasing occur to meet out the lactation demand, the concentration of lipoprotein increases by increasing the uptake of lipids in the liver through high tissue mobilization, food intake and synthesis of steroid hormones and lipoproteins (36). 
Table 3. Alteration in some blood biochemical parameters of Iraqi Nuaemie ewes during preand post-partum periods (Mean $\pm \mathrm{SE}$ )

\begin{tabular}{|c|c|c|c|}
\hline $\begin{array}{l}\text { Periods } \\
\text { Parameters }\end{array}$ & pre-partum & day of lambing & post-partum \\
\hline Total protein g/dl & $7.8 \pm 1.08 a$ & $6.5 \pm 1.85 b$ & $6.9 \pm 1 . .24 b$ \\
\hline Albumin g/dl & $3 \pm 0.4 a$ & $3.8 \pm 0.6 \mathrm{a}$ & $3.5 \pm 0.9 \mathrm{a}$ \\
\hline Glucose $\mathrm{mg} / \mathrm{dl}$ & $66.7 \pm 13.4 b$ & $80 \pm 11.47 a$ & $55.2 \pm 18.27 c$ \\
\hline Urea mg/dl & $40 \pm 0.84 a$ & $30.23 \pm 0.45 b$ & $31.35 \pm 0.9 b$ \\
\hline Creatinine mg/dl & $2.2 \pm 1.69 a$ & $0.8 \pm 0.33 c$ & $0.9 \pm 0.29 b$ \\
\hline Cholesterol mg/dl & $130 \pm 2.77 a$ & $113 \pm 1.52 b$ & $100 \pm 0.35 c$ \\
\hline triglyceride $\mathbf{~ m g / d l}$ & $48 \pm 0.17 a$ & $35 \pm 0.95 b$ & $26 \pm 1.07 c$ \\
\hline LDL mg/dl & $30.2 \pm 0.46 c$ & $40 \pm 1.69 b$ & $59 \pm 2.06 a$ \\
\hline HDL mg/dl & $12 \pm 1.7 \mathrm{c}$ & $16 \pm 0.98 b$ & $29 \pm 1.8 \mathrm{a}$ \\
\hline
\end{tabular}

Means with different superscripts within each row differ significantly $(\mathbf{P} \leq \mathbf{0 . 0 5})$.

The concentrations of zinc, copper and iron are represented in the Figure (1). The zinc, and Iron concentrations were decreased significantly $(\mathrm{P} \leq 0.05)$ during post-partum period compared to the day of lambing and pre-partum periods while the copper concentration was increased during the prepartum period and decreased at the day lambing and post-partum periods. These results were in line with those reported by (12) (50) (9). Kulcu et al., (33) mentioned a correlation between plasma zinc status and events occurring during gestation and parturition. Decrease in zinc concentration in the present study may due to coppers inhibition of intestinal zinc absorption (18). In contrast with zinc and iron, serum copper concentrations was decreased during prepartum period and at the day of lambing.
These results agreed with those noticed by Hadiya et al., (19) who recorded increases in copper concentrations during post-partum period in cattle. The lower concentration of copper recorded in pre and at parturition could be due to increased transfer of this nutrient across the placenta and haemodilution during late pregnancy and at calving, together with initiation of ovarian follicular activity postpartum, leading to high circulatory estrogens which stimulate binding of copper with the proteins in liver and thereby increased concentration in plasma (36). In conclusion, the physiological status of animals have clearly effects on the blood haematological and biochemical parameters lambing Juaemie ewes, the measuring of these parameters give good indicator for the healthy state of ewes.

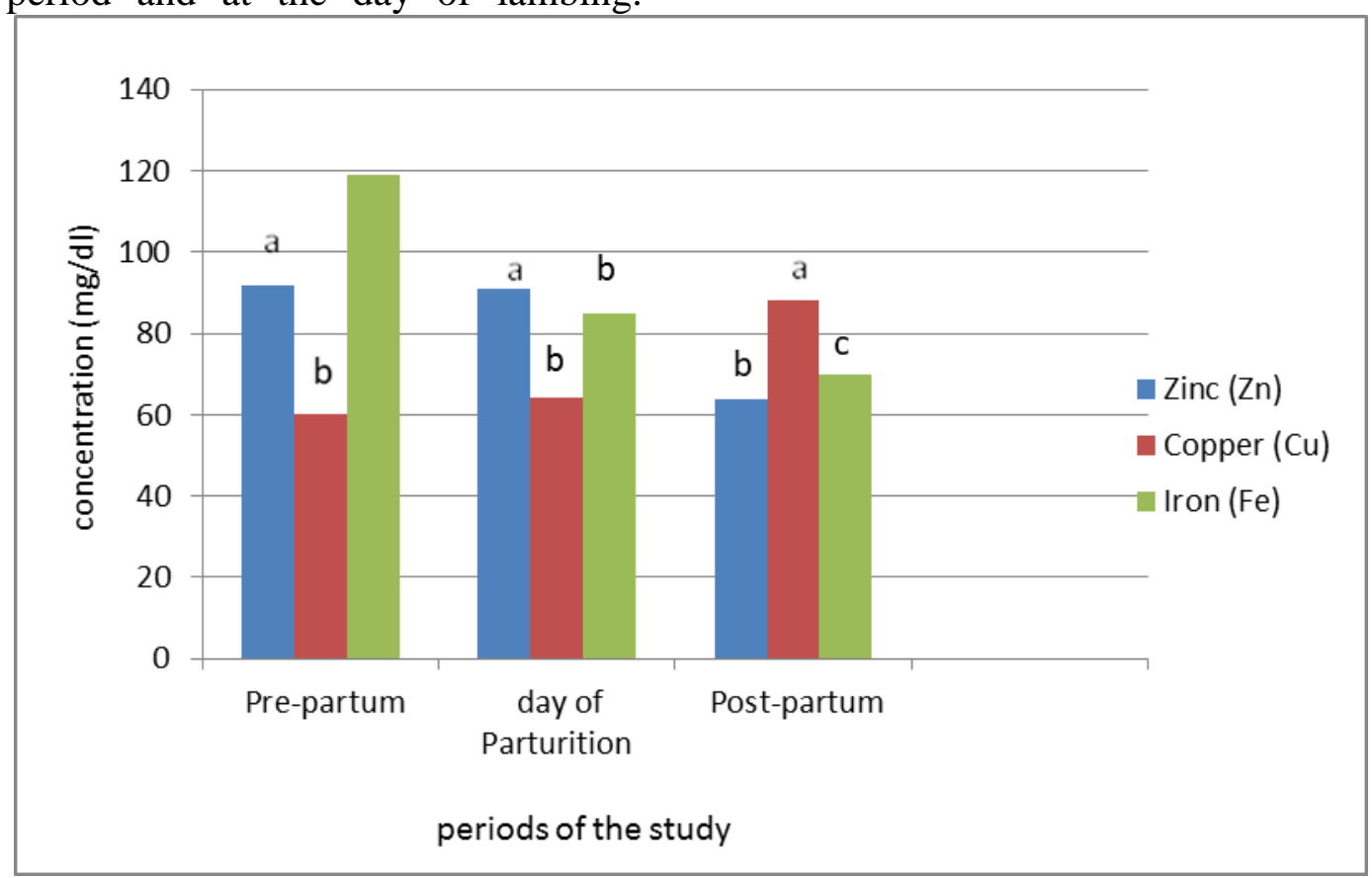

Figure 1. Alteration in serum zinc, copper and iron concentrations of Iraqi Nuaemie ewes during pre- and post-partum periods (Mean $\pm \mathrm{SE})$

Means with different superscripts within each columns differ significantly $(\mathrm{P} \leq 0.05)$. 


\section{REFERENCES}

1. Abdelatif, A.M., M.E. El Nageeb, S.E.A. Makawi and A.M. Fadlalla. 2009. Blood constituents in cycling, gestation and lactation desert ewes (Ovis aries) in relation to dietary supplement. Glob Vet 3, 248-259

2. Abdulkareem, T.A. 2013. Some hematological and blood biochemical profile of Iraqi riverine buffaloes (Bubalus bubalis) duringdifferent gestation period.J.Buffalo Sci. (India), 2, 78-84

3. Abdulkareem, T.A. 2013. Some hematological and blood biochemical attributes of Iraqi riverine buffaloes (Bubalus bubalis)around calving and post- partum period.Al-Anbar J. Vet. Sci., 6 (1), 143-150

4. Abdul-Rahaman, Y.T., A.A. Mnati and W.M. Mohammed. 2018. Effect of different gestation periods on some physiological aspects of iraqi female dromedary camel (camelusdromedarius). Iraqi J. Agric. Sci. 49(4):494-707

5. Ahmad, I., A. Gohar, N. Ahmad and M. Ahmad. 2003. Haematological profile in cyclic, non-Cyclic and Endometritic CrossBred cattle. International Journal of Agriculture Biological, 5(3): 332-334

6. Al-Mohammed, N.T., K.M. Al-Rawi, M.A. Younis and W.K. Al-Morani. 1986. Principles of statistics ., Univ. Mousal

7. Al-Mujalli, A.A.M. 2008. Studies on some serum constituents of dairy cows in Saudi Arabia. Scientific J. King Faisal University (Basic andApplied Sciences) 9:1429

8. Alon, R., P.D. Kassner, C.M. Woldemar, E.B. Finger, M.E. Hemler and T.A. Springer. 1995. The integrin VLA-4 supports tethering and rolling in flow on VCAM-1.J Cell Biol $128,1243-1253$

9. Alonso, M.L. 2000. Arsenic, cadmium, lead, copper and zinc in cattle from Galicia, NW Spain, Sci. Total Environ. 246: 237-248

10. Antunovic, Z., J. Novoselect, H. Sauerwein, M.Speranda, M. Vegeraand and V. Pavic. 2011. Blood metabolic profile and some of hormone concentration in ewes during different physiological status. Bulg. J. Agric. Sci., 17(5): 687-695

11. Anwar, M.M., A.N. El-din and T.A. Taha. 2012. Changes in Some Hematological and Serum Biochemical Parameters During the First Week After Lambing in Six Consecutive
Parities in Some Egyptian Sheep Breeds. Egyptian J. Anim. Prod., 49: 293-302

12. Azab, M.E. and H.A. Abdel-Maksoud. 1999. "Changes in some hematological and biochemical parameters during prepartum andpostpartum periods in female Baladi goats," Small Ruminant Research, vol. 34, no. 1, pp. $77-85$

13. Bell, G.H., J.H. Davson and H. Scarborough. 1961. Textbook of Physiology and Biochemistry, fifth ed. Neil \& Co. Ltd., Edinburgh, UK, pp. 291-313, 988-1026

14. Charismiadou, M.A., J.A. Bizelis and E. Rogdakis. 2000. J Anim Phys Anim Nutr, 84, 61-72

15. Coles, H.E. 1986. Veterinary Clinical Pathology; $4^{\text {th }}$ ed, Saunders Company, Philadelphia , 2: 12-14

16. Dawsan, J., D. Ellies and J. Newton. 1968. Dirct estimation of copper in serum and urine by atomic absorption spectroscopy . Clin China .Acta.21:33

17. EL-Sherif, M. and F. Assad. 2001. Changes in some blood constituents of Barki ewes during pregnancy and lactation under semi-arid conditions. Small Ruminant Research 40, 269-277

18. Goran, G.V., V. Crivineanu, E. Rotaru, L. Tudoreanu and A. Hanganu. 2010. Dyanmics of some mineral elements in sheep colostrum. Romania; Bulletin UASVM, Veterinary Medicine. Vol.67, No.2:81-87

19. Hadiya, K.K., H.J Derashri, B.R. Devalia and R.G. Jani. 2010. Effect of Supplementation of Minerals and Enzymes on Service Period and Postpartum Plasma Minerals Profile in Crossbred Cows. Veterinary World, Vol.3 No.4 ; 173-176

20. Hassan, A., N. Al-Akkam, and M. Samak. 1982. Effects of various locational events and stage of pregnancy on locational trends, plasma hydrocortisone and blood hematology of cross-bred (Egyptian X Holstein) and buffalo (Bubalus bubalis) cows. World Rev of Anim Prod, 18: 71 - 79.

21.Henry, J. B. 1984. Clinical Diagnosis and management 17th ed, Sauders Publisher. 22.Iriadam, M. 2007. "Variation in certain hematological and biochemical parameters during the peri-partum period in Kilis does,"Small Ruminant Research, vol. 73, no. 1-3, pp. 54-57. 
23.Jacob, N. and V.P. Vadodaria. 2001. Levels of glucose and cortisol in blood of Patanwadi ewes around parturition, Indian Vet J, 78, 890-892.

24.Jain, N.C. 1986. The horse. Normal haematologic with comments on response to disease.In: Schalm's Vet Hematol, Jain NC (ed), pp: 140-177, Lea \& Febiger, ISBN 0812109422 9780812109429, Philadelaphia, USA

25.Johnsen and R. Eliasson. 1987. Evaluation of a commercially available kit for the colorimetric determination of zinc. International Journal of Andrology, April 10 (2):435-440.

26.Juma, F.T., B.M. Mahmood and A.N. Yoseif. 2010. Effect of pregnancy stage and postpartum stage on some haematological and biochemical characteristics in Mountain Bleak goat Anbar. Anbar J. Vet. Sci. 3, 4452.

27.Kalasariya, R.M., A.J. Dhami, K.K. Hadiya, D.N. Borkhatariya and J.A. Patel. 2017. Effect of peripartum nutritional management on plasma profile of steroid hormones, metabolites, and postpartum fertility in buffaloes. Vet. World W: 302-310. 28.Kaneko, J.J., J.W. Harvey and M.L. Bruss. 2008. Clinical Biochemistry of Domestic Animals. 6th edn. Elsevier/Academic Press, Amsterdam.

29.Karapehlivan, M., E. Atakisi, M. Citil, O. Kankavi and O. Atakisi. 2007. Serum sialic acid levels in calves with pneumonia. Vet. Res. Commun., 31: 37-41.

30.Kataria, N., A. K. Kataria, V. K. Agarwal, S.L. Garg and M. S. Saini. 2002. Effect of seasonal water restriction on erythrocytic and leucocytic indices in camel. Ind. J. Anim. Health., 41: 24-28.

31.Kehrli, M.E., B.J. Nonnecke, J.A. Roth. 1989. Alteration in bovine lymphocyte function during the periparturient period. Am. J. Vet. Res. 50, 215-220.

32.Kim, I.H., K.J. Na and M.P. Yang. 2005. Immune responses during the peripartum period in dairy cows with postpartum endometritis. J. Reprod Dev. 51: 757-764. 33.Krajnicakova, M., G. Kovac, M. Kostecky, I. Valocky, I. Maracek, I. Šutiakova and L. Lenhardt. 2003. Selected clinical-biochemical parameters in the puerperal period of goats.
Bulletin of the Veterinary Institute Pulawy. 47, 177-182.

34.Kulcu, R. and F. Yur. 2003. A study of some serum mineral levels before and during pregnancy and during lactation period of sheep and cattle. Biol Trace Element Res, 92: 275-279.

35.Meglia, G.E., A. Johannisson, L. Petersson and K.P. Waller. 2001. Changes insomeblood micronutritiens, leukocytes and neutrophil expression of adhesion molecules in periparturient dairy cows. Acta Vet Scand 42, 139-150.

36.Mehere, Y. S., B.A. Talvelkar, B.T. Deshmukh, A.S. Nagvekar and S.D. Ingole. 2002. Hematological and trace element profile during peripartum period in crossbred cows. Indian J. Anim. Sci. 72 (2): 148-150. 37.Mohri, M., K. Sharifi and S. Eidi. 2007. Hematology and serum biochemistry of Holstein dairy calves: age related changes and comparison with blood composition in adults. Research in Veterinary Science, T.83. P. 3039.

38.Ozpinar, A., M. D. Şuşut and A. Firat. 2004. Changes in selected blood serum indices before and after parturition in mares. Medycyna Wet.,60(12).

39.Paape, M.J., A.V. Capuco, A. Lefcourt, C. Burvenich and R.H. Miller. 1992. Physiological response of dairy cows to milking. In: Ipema AH (ed.) Proc Int Symp on Prospects for Automatic Milking, Wageningen Netherlands, 23-25 November, PUDOC Scientific Publishers, EAAP Publications 65, 93-105.

40.Pandey, V., R. Nigam, P.R. Singh, S.P. Singh and A. Kumar. 2016. Plasma leptin and biochemical profile around parturition inprimiparous Shahiwal cows. Ruminant Sci. 5(2): 227-233.

41.Piccinini, R., E. Binda, M. Belloti, G. Casirani and A.Zecconi. 2004. The evaluation of non-specific immune status of heifers in field conditions during the periparturient period. Vet Res 35, 539-550. 42.Preisler, M.T., P.S. Weber, R.J. Tempelman, R.J. Erskine, H. Hunt and J.L. Burton. 2000. Glucocorticoid receptor downregulation in neutrophils of peri-parturient cows. Am J Vet Res. 61: 14-19. 
43.Schlumbohm C, and J. Harmeyer 2004. J Dairy Sci, 87 (2): 350-358.

44.Silanikove, N. 2000. The physiological basis of adaptation in goats to harsh environments. Small in blood corticosteroid concentration, but species Ruminant Res, 35: 181-193.

45.Taghipour, B., H.A. Seifi and M. Mohri. 2010. Variations of energy related biochemical metabolites during periparturition period in fat-tailed baloochi breed sheep. Iranian J. Vet. Sci. and Tech; 2: 85-92. 46.Tietz, N.W. 1999. Text book of Clinical Chemistry. $\quad 3^{\text {rd }} \quad$ Ed.C.A.Burtis, E.R. Ashwood,W.B. Saunders, pp 477-530. 47.Ullrey, D.E., E.R. Miller, C.H. Long and B. H. Vincent. 1965. "Sheep hematology from birth to maturity, II. Leukocyte concentration and differential distribution,"Journal of
Animal Science, vol. 24, pp. 141-144. 48.Vihan, V.S. and P. Rai. 1983. Metabolic profiles at different physiological stages in sheep and goat. Indian J. Vet. Med. 3: 1-8. 49.Yildiz, A., E. Balikci and F. Gurdogan. 2005. Serum mineral levels at pregnancy and postpartum in single and twin pregnant sheep. Biolog. Trace Elemn. Res. 107: 247253.

50.Yokus, B. and U.D. Cakir. 2006. Seasonal and physiological variations in serum chemistry and mineral concentrations in cattle. Biolog. Trace Elemn. Res. 109: 255-266.

51.Zumbo, A., A.R. Di Rosa, S. Casella and G. Piccione. 2007. Changes in some blood haematochemical parameters of Maltese goats during lactation. J. of Anim. and Vet. Adv. 6: 706-711. 